\title{
Malmquist Productivity Index Approach in Assessing Performance of Commercial Banks: Evidence from Nepal
}

\author{
Hari Prasad Pathak, PhD *
}

\begin{abstract}
Using the DEA-based Malmquist total factor productivity index, this article measures the total factor productivity of Nepalese commercial banks during the period 2010-2011 to 2016-2017. It also examines whether the ownership structure and size of banks affect their efficiency.An input-oriented DEA model is used with aggregate panel data covering all the 28 commercial banks that are currently operating in Nepal. This article adopts constant returns to scale approach to measure and compare the efficiency and productivity of banks and to establish a benchmark for their performance.Interest expense, operating noninterest expense, deposits and labor are used as inputs variables and interest income, operating non-interest income and loan and advances as outputs variables. These data are extracted from the annual reports of the respective commercial banks. The mean efficiency score measured in terms of total factor productivity changeresulted 1.008, which indicates that the efficiency level of Nepalese commercial banks has been increasingvery slowly at the rate of $0.8 \%$ annually. Ownership structure of the banksinfluences marginallyon the efficiency level of banks. The domestic private banks are relatively more efficient than the joint venture banks and the latter are comparatively more efficient than the public banks.The size of banks makes no significant difference in the efficiency level of banks.
\end{abstract}

Key Words: Bank, DEA, Malmquist productivity index, Performance

JEL Classification: G21

* Associate Professor, Faculty of Management, Prithvi Narayan Campus, Pokhara. Email: haripathak75@gmail.com, Phone: +977-61419108 Mobile: 9846036397

I am thankful to the Research Committee, Prithvi Narayan Campus, Tribhuvan University for the research grant which made this study possible. 


\section{INTRODUCTION}

The Nepalese financial system development has a very recent history. Till the 1980s, the banking sector was wholly owned by the government, with Nepal Bank, Rastriya Banijya Bank, Agricultural Development Bank, and Nepal Rastra Bank being the pillars of financial institutions in Nepal. The entry of other development banks, finance companies, micro-finance companies, savings and credit cooperatives and non-government organizations (NGOs) for limited banking transactions started after 1992. Nepalese financial system saw a rapid growth after the liberalization policies adopted by the nation since 1980. This growth was not only in the number of entities, but also in terms of the varieties of products and services and adoption of the newer technologies (Nepal Rastra Bank, 2017). With economic liberalization, and focus on the private sector development, some foreign banks have been established as joint venture banks in Nepal. Along with this, came a trend of establishing domestic private banks and other financial institutions, and thus the Nepalese financial system has shown a tremendous growth of banking sector within a short time span. By the end of mid July 2018, there were 28 commercial banks, 33 development banks, 25 finance companies and 63 micro-finance companies. The number of branches of banks and financial institutions stood at 6,418 across the nation in mid-June 2018. These include 2,919 branches of commercial banks, 951 of development banks, 183 of finance companies and 2,365 of microfinance institutions (Nepal Rastra Bank, 2018).

The banking sector in Nepal is one of the most important players in the economy. The country's banks, which are public, joint venture and private, provide capital for industry, construction, tourism, trade and many other sectors. The banks are also the most heavily traded securities on the Nepal Stock Exchange (NEPSE). Therefore, analysis of bank achievements in terms of productivity and efficiency is important from the point of view of depositors, investors, creditors, and regulators. It is also important from the perspective of the bank's management as they can judge not only their own performance but also can benchmark their performance with their counterparts. Therefore, the major focus of this paper is to examine how the commercial banks in Nepal are performing and to appraise annual change in their efficiency and productivity level. 
Efficiency level of the bank is measured to assess how well it is doing. Efficiency can be defined as a level of performance that describes a process that uses the lowest amount of inputs to create the greatest amount of outputs (Aikaeli, 2008). There are different approaches to analyzing the efficiency and performance of financial institutions which can be broadly categorized as parametric and nonparametric (Berger \& Humphery, 1997). This study has employed DEA-based Malmquist productivity index approach, a non-parametric quantitative model, for measuring the relative efficiencies of Nepalese commercial banks. DEA has been chosen for this study because it has proved to be a popular technique for performance analysis in general but particularly for the banking sector (Ramanathan, 2003). The banking sector has a series of characteristics that make it particularly suitable for study through DEA; the nature of its multiple inputs and outputs, the non-linearity of its input-output relationships, and the difficulty of drawing on market price mechanism for some of them. DEA is particularly suited to working with limited sample size (Evanoff \& Israilevich, 1991), and is thus appropriate for use in Nepalese context where there are only 28 commercial banks in operation in the time of this study.

The global banking crisis of 2008 brought to the fore the importance of performance measurement of banking institutions and according to Olweny and Shipho (2011) the crisis demonstrated the importance of bank performance to both national and international economies and the need to keep it under surveillance at all the times. Apart from the regulators, bank performance is of utmost importance to other stakeholders like depositors, bank managers, and investors. Hamid and Azmi (2011) state that in a competitive financial market, bank performance provides signal to depositors and investors alike, on whether to invest or withdraw funds from a bank. Similarly, regulators around the world use analysis of bank performance for its regulation purposes and to monitor developments or any pertinent issues to preserve the banking system stability and the financial system as a whole.With the periodic appraisal of performance, a bank can reduce operating risk, develop growth strategy and minimize its expenses to a considerable extent. At this backdrop,it is a matter of interest to know to what extent Nepalese commercial banks are efficient, and how much do they differ among each other with respect to their productivity scores?Similarly, 
do the ownership structures and size of banks affect their efficiency?To deal withthese issues, it is necessary to compare annual changes in the productivity of individual banks and identify general trends in the productivity of the banking sector as a whole.It is also required to compare the relative performance between the private, joint venture and public banks and to evaluate the effect of size on performance. In this context, the paper aimsat analyzing the efficiency levels of the Nepalese commercial banks and establishing benchmarks among these banks. The study also aims to investigate the effect of ownership type and asset size of banksontheir efficiency.

The research questions and the objectives stated in the foregoing paragraph form the basis to test thefollowing hypotheses.

H1: Ownership structure of banks makes significant difference in the increment of their efficiency and productivity level.

$\mathrm{H} 2$ : Size of the banks makes significant difference in the increment of their efficiency and productivity level.

The paper is organized into five sections. Following introduction in this section, Section II provides literature survey while Section III details out the data, methods and the tools for measuring banks' performance. Section IV discusses empirical evidence and Section V delivers the conclusion.

\section{LITERATURE SURVEY}

\subsection{Functions of Banks}

Banks are identified by the functions they perform in the economy. They are involved in transferring funds from savers to borrowers (financial intermediation) and in paying for goods and services (Rose \& Hudgins, 2008). Historically, banks have been recognized for the great range of financial services they offer-from checking accounts and savings plans to loans for businesses, consumers, and governments. However, bank service menus are expanding rapidly today to include investment banking, insurance protection, financial planning, advice for merging companies, the sale of risk-management services to businesses and consumers, and numerous other innovative services including fintech. Banks no 
longer limit their service offerings to traditional services but have increasingly become general financial-service providers. Nepalese commercial banks are also offering a wide range of services to their clients by taking the advantage of recent innovations in banking sector in the international arena.They are adopting the new technology and innovations collaborating with the foreign banks through joint venture and strategic partnership.

\subsection{Banks' Business Models}

Banks' business models evolve over time in response to changes in the economic and financial environment as well as to new rules and regulations. "Just as any other firm, a bank seeks a competitive edge by exploiting its comparative advantages in terms of access to specialized resources, available market opportunities and managerial skill. The result of this effort is a business model that emphasizes some activities as opposed to others, and that is reflected, inter alia, in the bank's balance sheet composition" (Roengpitya, Tarashev, Tsatsaronis, $\&$ Villegas, 2017, p. 2). The business models that are applied in bank management are various, and by continuous innovation in this field banks strive to secure a significant competitive advantage in the market (Jatic \& Ilic, 2018). Recent years have seen the strong competition in the global market and continuous seeking for the business models that could secure long-term business success to the banks. Innovations have been implemented in every segment of the banking business, and development of business models and strategies is the priority at every level of management in today's banks.

Roengpitya et al. (2017) classify banks into four business models. Two models are alternative versions of a commercial banking model, one that relies mainly on retail sources of funding and one that puts more emphasis on wholesale sources. These two models are quite stable, in the sense that the balance sheet characteristics of the typical constituent bank change little when experiment with different sets of input variables. A third model is thetrading model, where banks hold larger securities portfolios funded in the interbank and wholesale markets. The fourth one is theuniversalmodel, which blends characteristics of the other three business models. Farne and Vouldis (2017) also indicate the co-existence of four distinct business models: traditional commercial, complex commercial, 
wholesale funded and securities holding banks. Nepalese banks are found performing wholesale and retail banking. They do not hold significant size of securities portfolios. They invest basically in government securities with the primary motive of maintaining liquidity.

\subsection{Productivity and Efficiency}

Bank performance is often assessed in terms of their productivity and efficiency.Productivity is the ratio between an output and the factors that make it possible. Productivity change occurs when an index of outputs changes at a different rate than an index of inputs does. This ratio is easy to compute if the unit uses a single input to produce a single output. On the contrary, if the production unit uses several inputs to produce several outputs, then the inputs and outputs have to be aggregated so that productivity remains the ratio of two scalars. Similar, but not equal, is the concept of efficiency. Even though, in the efficiency literature many authors do not make any difference between productivity and efficiency. For instance, Sengupta (1995) and Cooper, Seiford and Tone (2000) define both productivity and efficiency as the ratio between output and input.Instead of defining the efficiency as the ratio between outputs and inputs, it can be described as a distance between the quantity of input and output, and the quantity of input and output that defines a frontier, the best possible frontier for a firm in its cluster (industry).

In conclusion, both productivity and efficiency can be defined in different ways. First, productivity and efficiency are different if the frontier is defined as the ratio of outputs over inputs and the later can only be determined through relative performance of decision making units1 (DMUs). Second, they are related since productivity growth could be decomposed into efficiency and technical change. The later refers to an upward shift of the production frontier as a result of change in technology while the former refers to the more efficient input used in production under the same technology.

Efficiency and productivity, anyway, are two cooperating concepts. The measures of efficiency are more accurate than those of productivity in the sense that they

1 In DEA literature, the organization under study is called a decision making unit (DMU). 
involve a comparison with the most efficient frontier.Productivity change can be calculated using index number techniques to construct a Fisher (1922) or Tornqvist (1936) productivity index. Both these indices require quantity and price information, as well as assumptions concerning the structure of technology and the behavior of producers. Productivity change can also be calculated using nonparametric techniques to construct a Malmquist (1953) productivity index. These latter techniques do not require price information or technological and behavioral assumptions, but they require the estimation of a representation of production technology. Nonparametric techniques are able not only to calculate productivity change, but also to identify the sources of measured productivity change.

\subsection{Malmquist Productivity Index}

A very useful approach for productivity measurement in DEA is the Malmquist productivity index (MPI), which was named after Professor Sten Malmquist, on whose ideas the MPI is based, and was further introduced by Caves, Christensen and Diewert (1982). The MPI calculates the relative performance of a DMU at different periods of time using the technology of a base period. Fare, Grosskopf, Lindgren and Roos (1992) combined the efficiency measurement of Farrell (1957) with the productivity measurement of Caves, Christensen and Diewert (1982) to construct a DEA-based MPI and decomposed it into two components, one of which measures efficiency changes and the other measures technical changes.

Sathye (2002) used Malmquist index to analyze productivity changes from 19951999 in a panel of 17 Australian banks to assess the effects of deregulation and the reforms introduced by the Wallis report of 1997. Sathye found a decline of $3.1 \%$ in technical efficiency over the period and of $3.5 \%$ in the total factor productivity index, although annual productivity grew by $1.3 \%$. Using DEA window analysis,Webb (2003) investigated the relative efficiency levels of large UKretail banks during the period of 1982-1995. He found that during the period the mean inefficiency levels of UK retail bankswere low compared to past studies on UK banking industry. Applying three inputs namely fixed assets, number of employees, and deposits and loans and securities portfolios as outputs, Reisman, Daouas, Oral, Rebai, and Gattoufi (2003) investigated the impact of deregulation 
on the efficiency of eleven Tunisiancommercial banks during 1990 to 2001 . They followed the intermediationapproach to DEA with an extended window analysis. They found that deregulation had a positiveimpact on Tunisian commercial banks' overall efficiency. Avkiran (2004) applied a three-year window to a sample of 10 Australian trading banks during the period of1986-1995, and found that Australian trading banks exhibited deteriorating efficiencylevels during the earlier part of the studies, before progressively trending upwards in thelatter part.

Hassan (2005) examined the relative cost, profit, X-efficiency and productivity of the world Islamic banking industry. Employing a panel of banks during 19932001, he used both the parametric (stochastic frontier approach) and nonparametric (data envelopment analysis) techniques as tools to examine the efficiency of the sample banks. He found that the Islamic banks were more profit efficient, with an average profit efficiency score of $84 \%$ under the profit efficiency frontier compared to $74 \%$ under the stochastic cost frontier. Sufian and Majid (2007) examined different indices namely productivity change, technological changeand efficiency change as well as scale efficiency, under intermediation approach. The other part of the study intendedto examine whether the domestic banks and foreign banks were drawn from the same environment.The findings oftheir study indicated that Malaysian Islamic bank productivity exhibited an inverted $U$ shaped behavior during theperiod of study. On another case domestic banks exhibited higher productivity growth than foreign banks.

Using data envelopment analysis and Mamlquist total factor productivity index, Sinha and Chatterjee (2008) made comparison of fund based operating performance and total factor productivity growth of selected Indian commercial banks for the five year period 2000-01 to 2004-05. Their findings revealed that the mean technical efficiency of the private and foreign banks was somewhat higher than the public sector banks. However, public sector commercial banks exhibited higher Malmquist index than the private sector banks. Sufian and Habibullah (2010) investigated the efficiency of the Thai banking sector from 1999 to 2008. Their results show that inefficiency in the Thai banking sector emerges predominantly from scale efficiency. 
Thagunna and Poudel (2013)conducted a study covering a period of four years andtaking 24 commercial banks in their sample. They used DEA basic model to analyze the efficiency level of Nepalese commercial banks. They found that efficiency level of banks in Nepal is relatively stable and has increased in overall. Their findings did not show significant effect of the ownership type and the asset size of a bank on its efficiency. Neupane (2013), taking a sample size of 22 commercial banks and using five years data, analyzed the productivity of Nepalese commercial banks employing Malmquist Index. He concluded that the productivity change of commercial banks has improved over the sample period and that the increase in productivity change in commercial banks is due to the technical progress rather than efficiency components. Adjei-Frimpong, Gan, Ying, $\mathrm{Hu}$, and Cohen (2015) foundthat New Zealand retail banks generally have high levels of efficiency. In addition, the results suggest that a large part of overalltechnical inefficiency of retail banks could be attributed to scale inefficiency rather than pure technical inefficiency.Furthermore, the results indicate that New Zealand banks experienced a modest productivity growth rate over the 2007to 2011 period. Garamu (2016) assessed the technical efficiency and productivity of Ethiopian commercial banks using a Malmquist productivity index approach. The study has shown that the total factor productivity change during the study period is $0.956 \%$ which shows regress in total factor productivity. Bahrini (2017) measured and analyzed the technical efficiency of Islamic banks in the Middle East and North Africa region during the period 2007-2012. The results showed that Islamic banks had stable efficiency scores during the global financial crisis (2007-2008) and in the early post-crisis period (2009-2010). Using DEA, Pathak (2017) analyzed the post-merger operating performance of Nepalese financial institutions. His sample includes 23 merger cases of 50 banks and financial institutions, in which seven were commercial banks and the rest were development banks and finance companies. He found very small changes (statistically insignificant) in the post merger efficienciesof financial institutions.

\subsection{Research Gaps}

The literature on bank efficiency measurement shows that a good number of studieshave been carried out using DEA Malmquist Index approach in both developed and developing countries. But, in the context of Nepal, very few 
studies are found in this field. Earlier Nepalese studies were based on small samples and have not covered the public banksin their studies, arguingthat there were big differences in paid-up capital and total assetsbetween public commercial banks and other banks. This situation has been changed now as all the non-public banks have increased more than four-folds in their paid-up capital in the last few years because of the direction of Nepal Rastra Bank (the central bank of Nepal) to increase their capital base.This study covers public, private as well as joint venture banks and also use larger sample size than earlier Nepalese studies by incorporating all the 28 commercial banks that are in the operation. The study period covered by the current study is longer and recent than that of earlier studies. This study, thus, fills the gaps that were present in terms of coverage of public banks, sample sizeand recency of the study period.

\section{DATA AND METHODS}

The study used the financial data extracted from annual reports of sampled banks from the period of fiscal year 2010-2011 to 2016-2017. It covers all the 28 commercial banks that wereoperating in Nepal during the study period. Basic DEA model has been used to identify the relatively efficient banks. Similarly, DEA-based Malmquist productivity index (MPI) approach has been used to examine the productivity change of the banks over time. Regression modelshave been used to find the effect of ownership structure and size on bank efficiency.

Total deposits, staff expenses, interest expenses, and operating non-interest expenses have been used as input variables and total loans and advances, interest income and operating non-interest income as output variables for the DEA model. Input oriented model of DEA based on intermediation approach has been used by taking the assumption of constant return to scale (CRS). The study used DEAP version 2.1, a computer program developed by Coelli (1996) to compute Malmquist productivity index.

As the DEAP computer program requires the data be listed in a text file and expects the data to appear in aparticular order, the data taken from the annual reports of the banks were first put into a text file in the computer. Following the requirements of the DEAP program, data were listed by observation (i.e. one row 
for each bank). Similarly, each output and each input were listed in their respective columns, with all outputs listed first and then all inputs listed (from left to right across the file). All data were listed for year 1 first, followed by the year 2 data listed in the same order (of the banks) and so on. To make the panel balanced, all firms were observed all time periods of seven years. Finally, data were transferred to a data file created in DEAP program and a command was given to execute the instructions that were written in an instruction file created in DEAP program. The program then producedan output file. The output was imported into a spreadsheet program for further manipulation into tables.

\section{Multifactor Productivity Indexes}

The productivity of a firm is measured by the quantity of output produced per unit of input (Meenakumari, 2009). In the single-output, single-input case, it is merely the ratio of the firm's output and input quantities. Thus if in period 0 a firm produces output $\mathrm{y}_{0}$ from input $\mathrm{x}_{0}$, its productivity $(\Pi)$ is,

$$
\Pi_{0}=\mathrm{y}_{0} / \mathrm{x}_{0}
$$

Similarly, in period 1 , when output $\mathrm{y}_{1}$ is produced from input $\mathrm{x}_{1}$, the productivity is,

$$
\Pi_{1}=\mathrm{y}_{1} / \mathrm{x}_{1}
$$

Moreover, the productivity index $(\pi)$ in period 1 with period 0 as the base is,

$$
\pi_{1}=\frac{\Pi_{1}}{\Pi_{0}}=\frac{y_{1} / x_{1}}{y_{0} / x_{0}}=\frac{y_{1} / y_{0}}{x_{1} / x_{0}}
$$

This productivity index shows how productivity of the firm has changed from the base period. The rate of productivity growth is the difference in the growth rates of the output and input quantities respectively.

When multiple inputs and/or outputs are involved, it is necessary to replace the simple ratios of the output and input quantities in equation (3) by a ratio of quantity indexes of output and input (Meenakumari, 2009). In this case, the index of multifactor productivity is, 


$$
\pi_{1}=\frac{\Pi_{1}}{\Pi_{0}}=\frac{Q_{y}}{Q_{x}}
$$

Where, $\mathrm{Q}_{\mathrm{y}}$ and $\mathrm{Q}_{\mathrm{x}}$ are the output and input quantity indexes of the firm in period 1 with period 0 as the base.

\section{The Malmquist Productivity Index Model Specification}

Consider that in time period $t$, the DMU is using input $x^{t}$ to produce output $y^{t}$. The input distance function $\mathrm{D}^{\mathrm{t}}\left(\mathrm{x}^{\mathrm{t}}, \mathrm{y}^{\mathrm{t}}\right)$ is defined on the technology, $\phi^{\mathrm{t}}$, as the maximal feasible contraction of $x^{t}$ that still enables the production of $y^{t}$.

$$
D^{t}\left(X^{t}, Y^{t}\right)=\max \left\{\lambda:\left(\frac{X^{t}}{\lambda}, Y^{t}\right) \in \phi^{t}\right\}
$$

$D^{t}\left(X^{t}, Y^{t}\right)$ refers to the input distance function which evaluates period $t$ data relative to the technology in period $t, \phi^{\mathrm{t}}$. The technology of production, $\phi^{\mathrm{t}}$, consists of all input-output vectors that are technically feasible for a certain production process.

The MPI is based on distance functions, output distance functions for an outputoriented index and input distance functions for an input-oriented index. The index is applied to the measurement of total factor productivity change over time, and can be decomposed into an efficiency change index and a technological change index.

Following Caves, Christensen and Diewert (1982), the MPI can be expressed in terms of distance function (D) as equation (6) and equation (7) using the observations at time $t$ and $t+1$. The period $t$-based MPI is defined as:

$$
M P I_{I}^{t}=\frac{D_{I}^{t}\left(x^{t+1}, y^{t+1}\right)}{D_{I}^{t}\left(x^{t}, y^{t}\right)}
$$

Where, $\mathrm{x}$ denotes input and $\mathrm{y}$ denotes output of DMU; $\left(\mathrm{x}^{\mathrm{t}}, \mathrm{y}^{\mathrm{t}}\right)$ and $\left(\mathrm{x}^{\mathrm{t}+1}, \mathrm{y}^{\mathrm{t}+1}\right)$ denote the input and output data sets relative to time periods $t$ and $t+1$ respectively. Thus, $\left(\mathrm{x}^{\mathrm{t}}, \mathrm{y}^{\mathrm{t}}\right)$ and $\left(\mathrm{x}^{\mathrm{t}+1}, \mathrm{y}^{\mathrm{t}+1}\right)$ also represent production points at time $\mathrm{t}$ and $t+1$, respectively. The subscript 'I' denotes the input orientation of MPI model. 
Using the technology at $t+1$ as the reference, the period $(t+1)$-based MPI is defined as:

$$
M P I_{I}^{t+1}=\frac{D_{I}^{t+1}\left(x^{t+1}, y^{t+1}\right)}{D_{I}^{t+1}\left(x^{t}, y^{t}\right)}
$$

The geometric mean of two MPIs in equation (6) and equation (7) gives the equation (8), which is the measure of Malmquist total productivity change index (Coelli,1996; Fare, Grosskopf, Norris, \& Zhang,1994).

$$
M P I_{I}^{G}=\left(M P I_{I}^{t} * M P I_{I}^{t+1}\right)^{1 / 2}=\left[\left(\frac{D_{I}^{t}\left(x^{t+1}, y^{t+1}\right)}{D_{I}^{t}\left(x^{t}, y^{t}\right)}\right) \cdot\left(\frac{D_{I}^{t+1}\left(x^{t+1}, y^{t+1}\right)}{D_{I}^{t+1}\left(x^{t}, y^{t}\right)}\right)\right]^{1 / 2}
$$

MPI in equation (8) measures the productivity of the most recent production point $\left(x^{t+1}, y^{t+1}\right)$ relative to the earlier production point $\left(x^{t}, y^{t}\right)$. This is to say the efficiency change is obtained by calculating the ratio of efficiency in $(t+1)$ period in proportion to efficiency in $t$ period. The index uses period $t$ technology and the next period $t+1$ technology. The measure of productivity growth is a geometric mean of two MPIs. The $\mathrm{MPI}_{\mathrm{I}}^{\mathrm{G}}$ value greater than one implies total productivity growth from period $t$ to the next period $t+1$ while a value less than one indicates total productivity decline. $\mathrm{MPI}_{\mathrm{I}}^{\mathrm{G}}=1$ indicates stagnation in productivity between the period $t$ and $t+1$.

The input oriented geometric mean of MPI (i.e. Malmquist total productivity change index) can be decomposed using the concept of input oriented efficiency change $(\mathrm{EFFCH})$ and input oriented technology change $(\mathrm{TECHCH})$ as given in equation (9).

$$
M P I_{I}^{G}=\left(E_{F F C H}\right) \cdot\left(T_{E C H C H}^{G}\right)=\left(\frac{D_{I}^{t+1}\left(x^{t+1}, y^{t+1}\right)}{D_{I}^{t}\left(x^{t}, y^{t}\right)}\right) \cdot\left[\left(\frac{D_{I}^{t}\left(x^{t}, y^{t}\right)}{D_{I}^{t+1}\left(x^{t}, y^{t}\right)}\right) \cdot\left(\frac{D_{l}^{t}\left(x^{t+1}, y^{t+1}\right)}{D_{I}^{t+1}\left(x^{t+1}, y^{t+1}\right)}\right)\right]^{1 / 2}
$$

The first and second terms represent the efficiency change and the technology change respectively. MPI given by Equation (8) and Equation (9) can be defined using DEAlike distance function. That is, the components of MPI can be derived from the estimation of distance functions defined on a frontier technology. Fare, Grosskopf, Norris, and Zhang (1994) provided the formal derivation of MPI and it is the most popular method among the various methods that have been developed to estimate a production technology (Coelli, Rao, O'Donnel, \& Battese, 2005). By 
utilizing both CRS and VRS DEA frontiers to estimate the distance functions in equation (9), the efficiency change $(\mathrm{EFFCH})$ can be decomposed into scale efficiency change $(\mathrm{SECH})$ and pure efficiency change $(\mathrm{PECH})$ components. A scale efficiency change (SECH) is given in equation (10).

$$
S E C H=\left[\left(\frac{D_{v r s}^{t+1}\left(x^{t+1}, y^{t+1}\right) / D_{r s}^{t+1}\left(x^{t+1}, y^{t+1}\right)}{D_{v r s}^{t+1}\left(x^{t}, y^{t}\right) / D_{c r s}^{t+1}\left(x^{t}, y^{t}\right)}\right) \cdot\left(\frac{D_{v r s}^{t}\left(x^{t+1}, y^{t+1}\right) / D_{\text {crs }}^{t}\left(x^{t+1}, y^{t+1}\right)}{D_{v r s}^{t}\left(x^{t}, y^{t}\right) / D_{\text {crs }}^{t}\left(x^{t}, y^{t}\right)}\right)\right]^{1 / 2}
$$

And a pure efficiency change $(\mathrm{PECH})$ is given in Equation (11).

$$
P E C H=\frac{D_{v r s}^{t+1}\left(x^{t+1}, y^{t+1}\right)}{D_{c r s}^{t}\left(x^{t}, y^{t}\right)}
$$

Thus, the multiplication of the efficiency change $(\mathrm{EFFCH})$ and technology change (TECHCH) yields the total factor productivity change. Similarly, efficiency change $(\mathrm{EFFCH})$ is the product of pure efficiency change $(\mathrm{PECH})$ [due to the VRS assumption] and scale efficiency change (SECH).

\section{Regression Model Specification}

This study estimates three models where the bank ownership structure and size have been regressed on bank efficiency. Bank efficiency has been measured in terms of CRS efficiency score using DEA method.

\section{Model 1}

Following model has been developed to analyze the effect of ownership structure on efficiency of bank.

$$
Y_{i}=\alpha+\beta_{1} \operatorname{STRUC}_{i}+\varepsilon_{i}
$$

$\mathrm{Y}_{\mathrm{i}}$ is the average CRS efficiency score of seven years and $\mathrm{STRUC}_{\mathrm{i}}$ is the ownership structure of the banks. Using dummy variables for the ownership structure of the banks, and taking domestic banks as reference group, the model is restated as:

$$
Y_{i}=\alpha+\beta_{1} S_{T R U C}+\varepsilon_{i}
$$


Where,

$Y_{i}=$ Average CRS efficiency score of seven years

$\mathrm{D}_{1}=$ dummy variable taking the value of 1 if the bank is public bank and zero otherwise

$\mathrm{D}_{2}=$ dummy variable taking the value of 1 if the bank is joint venture bank and zero otherwise.

\section{Model 2}

In order to analyze the influence of size on performance, banks with total assets of more than Rs. 100 billion has been categorized as large banks; banks with total assets lying in the range of Rs. 70 billion to Rs. 100 billion as medium sized banks and banks with total assets less than Rs. 70 billion as small banks. The researcher could not find any reliable literature regarding the classification of banks in Nepal with respect to the asset size. Therefore, the above classification has been made subjectively, dividing the total sample banks in such a way that they fall nearly equal number in three different sizes. The performance of the banks has been measured in terms of CRS efficiency score. Eichengreen and Gibson (2001) suggested that the effect of a growing bank's size on performance may be positive up to a certain limit. Beyond this point the effect of size could be negative due to bureaucratic and other reasons. The current study also expects the size to take a positive sign if banks are able to achieve economies of scale, but the coefficient of size may also be negative if they extend their business extensively in new areas forming a higher diversification of assets. The values of variables have been taken from the financial statements of fiscal year 2016-2017. The regression model is:

$$
Y_{i}=\alpha+\beta_{1} S I Z E_{i}+\varepsilon_{i}
$$

Since the banks are divided into three categories (small, medium and large) in terms of size, it is necessary here to use two dummy variables to facilitate the comparison. Taking small sized banks as reference group, the model is restated as:

$$
Y i=\alpha+\beta_{1} D_{1 i}+\beta_{2} D_{2 i}+\varepsilon_{i}
$$


Where,

$\mathrm{Y}_{\mathrm{i}}=$ Average CRS efficiency score of seven years

$\mathrm{D}_{1}=$ dummy variable taking the value of 1 if the bank is medium size bank, 0 otherwise

$\mathrm{D}_{2}=$ dummy variable taking the value of 1 if the bank is large size bank, 0 otherwise.

\section{Model 3}

In the absence of the standard classification of banks with respect to the asset size, the subjective classification of their size made in Model 2 could bias the results. To deal with this problem, the study develops Model 3 where SIZE of the banks is regressed on efficiency score leaving the continuous variable SIZE in Model 2 as it is without subdividing into small, medium and large classes. Natural logarithm value of the total assets (SIZE) has been used to minimize the non-linear relationship between the independent and dependent variables. The regression model is:

$$
\mathrm{Y}_{\mathrm{i}}=\alpha+\beta_{1} \operatorname{Ln}\left(\mathrm{SIZE}_{\mathrm{i}}\right)+\varepsilon_{\mathrm{i}}
$$

Where,

$Y_{i}=$ Average efficiency score of seven years

$\operatorname{Ln}\left(\mathrm{SIZE}_{\mathrm{i}}\right)=$ Size of the banks measured in terms of log of total assets.

\section{RESULTS AND DISCUSSION}

\subsection{Status of Financial Institutions in Nepal}

Since last few years, Nepalese banking industry has been going through the consolidation process with merger and acquisitions. This process has reduced significant number of financial institutions (FIs). The number of FIs is reduced to 189 bymid July 2018 from 272 in 2011 . The average non-performing loan ratio of the FIs stood at $1.66 \%$ in mid-April 2018. The number of branches of FIs stood at 6,418 in mid -June 2018. These include 2,919 branches of commercial banks, 951 
of development banks, 183 of finance companies and 2,365 of microfinance institutions. On an average, population served by per branch of FIs stood at 4,490 in mid-June 2018 compared to 5,809 a year ago. As of mid- May 2018, the number of deposit accounts in FIs stood at 22.5 million and loan accounts 1.29 million. The number of ATMs reached 2,624. Likewise, the number of mobile banking users reached 4 million and the internet banking users 784 thousand. The number of issued debit card stood at 5.24 million and credit cards 97 thousand (Nepal Rastra Bank 2018). Figure 1 shows changes in numbers of overall FIs and commercial banks in the last nine years period. The numbers of overall FIs were highest in 2011 while that of commercial banks picked in 2012 and they started to decline thereafter. But commercial banks have decreased in less proportion than other FIs. Thus, consolidation process has not remained effective in commercial bank sector compared to other financial sectors.

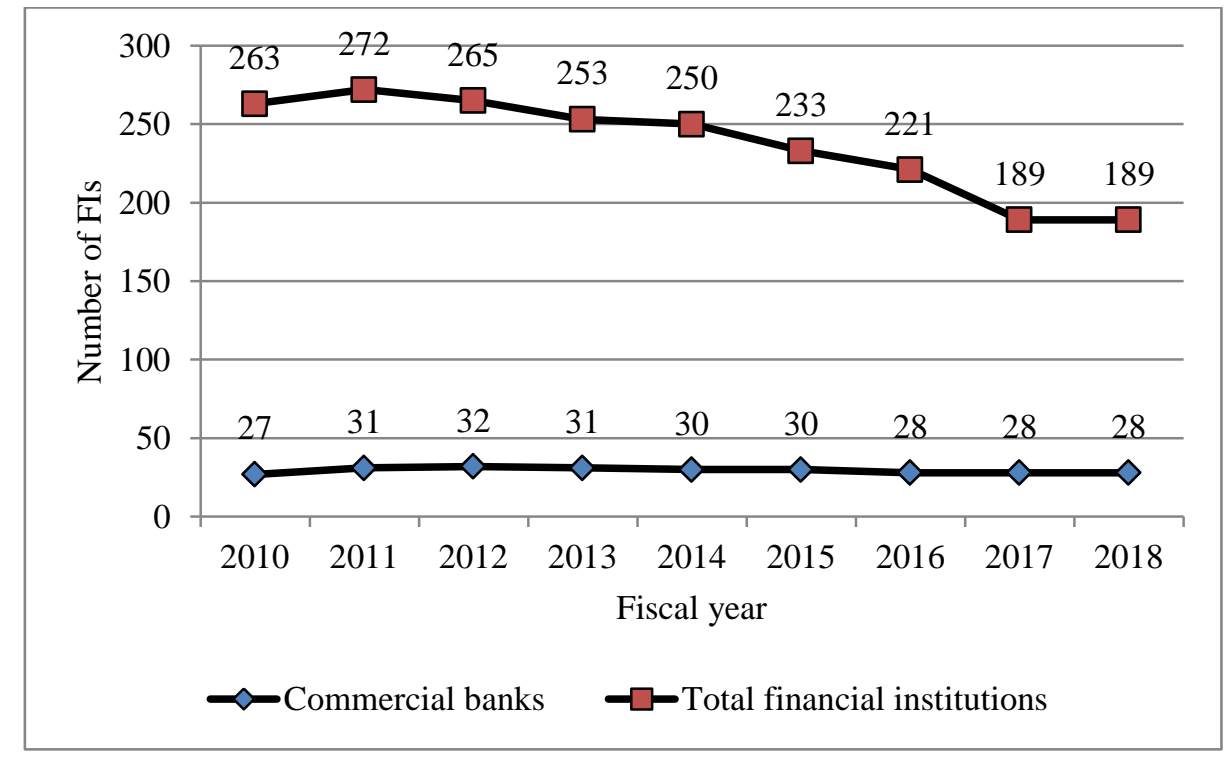

Figure1.Trend of financial institutions growth in number during last nine years

\subsection{Descriptive Statistics}

Table 1 presents the descriptive statistics of inputs and outputs variables of 28 sample commercial banks for the period 2010-2011 to 2016-2017. The large difference in the minimum and maximum value of variables indicates that 
commercial banks have been significantly increasing their business volume during the study period.

Table 1: Descriptive Statistics of Input and Output Variables from 2010-2011 to 2016-2017

(Rs. in '000)

\begin{tabular}{|c|c|c|c|c|c|c|c|}
\hline & \multicolumn{3}{|c|}{ Output variables } & \multicolumn{4}{|c|}{ Input variables } \\
\hline & $\begin{array}{c}\text { Total } \\
\text { loans, } \\
\text { advances } \\
\text { and bills } \\
\text { payable } \\
\text { (Rs) }\end{array}$ & $\begin{array}{c}\text { Interest } \\
\text { income } \\
(\mathrm{Rs})\end{array}$ & $\begin{array}{l}\text { Operatin } \\
\text { g non- } \\
\text { interest } \\
\text { income } \\
\text { (Rs) }\end{array}$ & $\begin{array}{c}\text { Total } \\
\text { deposits } \\
\text { (Rs) }\end{array}$ & $\begin{array}{c}\text { Staff } \\
\text { expenses } \\
\text { (Rs) }\end{array}$ & $\begin{array}{c}\text { Interest } \\
\text { expenses } \\
\text { (Rs) }\end{array}$ & $\begin{array}{c}\text { Operating } \\
\text { non-interest } \\
\text { expense } \\
\text { (Rs) }\end{array}$ \\
\hline Mean & $34,298,771$ & $3,709,775$ & 530,861 & $45,518,306$ & 596,331 & $1,811,991$ & 992,749 \\
\hline S.D. & $15,875,339$ & $1,195,182$ & 210,379 & $18,476,129$ & 244,157 & 482,989 & 342,941 \\
\hline Maximum & $17,402,260$ & $2,524,239$ & 278,653 & $23,672,819$ & 362,456 & $1,450,710$ & 615,082 \\
\hline Minimum & $61,050,973$ & $5,793,852$ & 876,573 & $74,637,612$ & $1,080,624$ & $2,881,549$ & $1,634,591$ \\
\hline
\end{tabular}

\subsection{Technical Efficiency Scores of the Banks Based on Basic DEAModel}

An attempt has been made here to measure the efficiency scores of the banks under study. Balanced panel data with 196 observations that appears in study period of seven years has been employed. Table 2 reports the measures of efficiency for the 28 commercial banks from fiscal year 2010-2011 to 2016-2017 using the basic DEA model under constant returns to scale (CRS) assumption. The value of unity represents the industry frontier; thus the firm with lower value than unity is more inefficient compared to values closer to one. Values of unity imply that the firm is on the industry frontier in the associated year whereas value less than unity imply that firm is below the frontier or technically inefficient. Banks having score of one is considered as benchmarking banks for rest of the peer banks. 
Table 2: Efficiency Level of Commercial Banks

\begin{tabular}{|c|c|c|c|c|c|c|c|c|}
\hline & \multicolumn{8}{|c|}{ Technical efficiency under CRS DEA for the fiscal year } \\
\hline & $2010 / 11$ & $2011 / 12$ & $2012 / 13$ & $2013 / 14$ & $2014 / 15$ & $2015 / 16$ & $2016 / 17$ & Mean \\
\hline ADBL & 1.000 & 1.000 & 1.000 & 1.000 & 1.000 & 1.000 & 1.000 & 1.000 \\
\hline BOK & 1.000 & 0.950 & 1.000 & 1.000 & 1.000 & 1.000 & 0.966 & 0.988 \\
\hline $\mathrm{CBL}$ & 1.000 & 0.996 & 0.932 & 1.000 & 1.000 & 0.915 & 0.970 & 0.973 \\
\hline CCBL & 1.000 & 1.000 & 0.939 & 0.995 & 0.965 & 0.973 & 1.000 & 0.982 \\
\hline CZBIL & 1.000 & 0.993 & 0.992 & 1.000 & 0.977 & 0.969 & 1.000 & 0.990 \\
\hline EBL & 0.998 & 1.000 & 1.000 & 1.000 & 0.982 & 0.936 & 0.976 & 0.985 \\
\hline GBIME & 0.959 & 1.000 & 0.942 & 1.000 & 1.000 & 0.969 & 0.896 & 0.967 \\
\hline HBL & 0.921 & 1.000 & 1.000 & 0.995 & 1.000 & 1.000 & 0.997 & 0.988 \\
\hline JBNL & 1.000 & 1.000 & 1.000 & 1.000 & 0.940 & 0.940 & 1.000 & 0.983 \\
\hline KBL & 0.982 & 0.978 & 0.968 & 0.985 & 0.938 & 1.000 & 0.960 & 0.973 \\
\hline LBL & 0.955 & 0.924 & 0.955 & 0.956 & 0.955 & 0.963 & 1.000 & 0.958 \\
\hline MBL & 0.973 & 0.845 & 0.902 & 0.946 & 0.944 & 0.949 & 0.982 & 0.934 \\
\hline MEGA & 0.907 & 1.000 & 1.000 & 1.000 & 1.000 & 1.000 & 1.000 & 0.987 \\
\hline NABIL & 1.000 & 1.000 & 1.000 & 1.000 & 1.000 & 1.000 & 1.000 & 1.000 \\
\hline NBBL & 1.000 & 0.922 & 1.000 & 1.000 & 1.000 & 1.000 & 1.000 & 0.989 \\
\hline NBL & 0.892 & 0.744 & 0.790 & 0.845 & 1.000 & 0.887 & 1.000 & 0.880 \\
\hline NCCBL & 0.947 & 0.934 & 0.933 & 1.000 & 0.936 & 0.918 & 0.913 & 0.940 \\
\hline NIBL & 1.000 & 1.000 & 1.000 & 1.000 & 1.000 & 1.000 & 1.000 & 1.000 \\
\hline NICA & 1.000 & 0.965 & 1.000 & 1.000 & 0.944 & 1.000 & 1.000 & 0.987 \\
\hline NMB & 0.984 & 0.939 & 0.931 & 0.961 & 0.944 & 0.952 & 0.982 & 0.956 \\
\hline NSBI & 0.840 & 0.825 & 0.747 & 0.860 & 1.000 & 0.925 & 0.927 & 0.875 \\
\hline PCBL & 1.000 & 1.000 & 1.000 & 1.000 & 1.000 & 1.000 & 1.000 & 1.000 \\
\hline PRVU & 0.826 & 0.883 & 0.987 & 0.958 & 0.940 & 0.846 & 0.886 & 0.904 \\
\hline RBBL & 0.787 & 0.737 & 0.782 & 0.855 & 1.000 & 0.930 & 1.000 & 0.870 \\
\hline SANIMA & 0.947 & 1.000 & 1.000 & 1.000 & 1.000 & 1.000 & 1.000 & 0.992 \\
\hline SBL & 0.942 & 0.988 & 1.000 & 1.000 & 0.996 & 0.999 & 0.977 & 0.986 \\
\hline SCBN & 1.000 & 1.000 & 1.000 & 1.000 & 1.000 & 1.000 & 1.000 & 1.000 \\
\hline SRBL & 1.000 & 0.907 & 0.922 & 0.966 & 0.969 & 0.966 & 0.947 & 0.954 \\
\hline Mean & 0.959 & 0.947 & 0.954 & 0.976 & 0.980 & 0.966 & 0.978 & 0.966 \\
\hline
\end{tabular}

Note. $\mathrm{ADBL}=$ Agriculture Development Bank Limited; $\mathrm{BOK}=$ Bank of Kathmandu Limited; $\mathrm{CBL}=$ Civil Bank Limited; $\mathrm{CCBL}=$ Century Commercial Bank Limited; CZBIL= Citizens Bank International Limited; EBL= Everest Bank Limited; GBIME= Global IME Bank Limited; HBL= Himalayan Bank Limited; JBNL= Janata Bank Nepal Limited; KBL= Kumari Bank Limited; LBL= Laxmi Bank Limited; $\mathrm{MBL}=$ Machhapuchchhre Bank Limited; MEGA= Mega Bank Nepal Limited; NABIL= NABIL Bank Limited; NBBL $=$ Nepal Bangladesh Bank Limited; NBL $=$ Nepal Bank Limited; NCCBL $=$ Nepal Credit and Commerce Limited; NIBL= Nepal Investment Bank Limited; NICA= NIC Asia Bank Limited; NMB= NMB Bank Limited; NSBI= Nepal SBI Bank Limited; PCBL= Prime Commercial Bank Limited; PRVU= Prabhu Bank Limited; RBBL= Rastriya Banijya Bank Limited; SANIMA = Sanima Bank Limited; SBL= Siddhartha Bank Limited; SCBN= Standard Chartered Bank Nepal Limited; SRBL= Sunrise Bank Limited. 
Under DEA method, input-oriented model is used to test if a DMU under evaluation can reduce its inputs while keeping the outputs at their current levels. Output-oriented model is used to test if a DMU under evaluation can increase its outputs while keeping the inputs at their current levels. This study has used input oriented model. Therefore, the banks with efficiency score of less than one are not using the same level of input as the peer banks with efficiency score of one are using to produce the same level of output. It means that banks with score lower than one have the potential to decrease their input to produce the same level of output. In Table 2, it is seen that, for the year 2010-2011, Himalayan Bank Limited (HBL) has an efficiency score of 0.92; it implies that HBL can decrease its inputs by eight percent (1-0.92), to produce the same level of outputs it currently has.

Agriculture Development Bank, Nabil Bank, Nepal Investment Bank, Prime Commercial Bank, and Standard Chartered Bank have been remained most efficient amongst their peers throughout the study period of seven years. Mega Bank, Sanima Bank, Nepal Bangladesh Bank also held the similar position with the exception in one of the initial years. Nepal Bank, Nepal SBI Bank, and Rastriya Banijya Bank remained relatively poor performer in terms of technical efficiency when compared to benchmark banks (having efficiency score of 1) identified by DEA. Their efficiency scores are below 0.900 .

The mean value, presented in the last row of the table, is the geometric mean of the efficiency in the particular year. The mean value shows that the technical efficiency under CRS method has decreased in fiscal years 2011-2012 and 20152016, whereas in the rest of the years it has increased. Many commercial banks experienced very low efficiency with compared to twelve benchmark banks identified by DEAin the fiscal year 2011-2012 with compared to other years. This shows that the relative performance of most of the commercial banks was poor in the fiscal year 2011-2012 compared to other years which can be attributed to various externalities such as unstable political situation, liquidity crunch, and tight regulatory measures among others. It is also observed that 12 out of 28 commercial banks were in industry frontier (CRS) in 2011-2012 compared to 17 out of 28 in 2013-2014 (CRS). Nevertheless, banks were able to increase their efficiency during the study period leaving two fiscal years (2011-2012 and 2015- 
2016) as exception. Hence it is inferred that commercial banks show satisfactory performance during the study period. However, it should be noticed that the banks with efficiency score of less than one are using more quantity of inputs with compared to the banks having efficiency score of one, to produce the same level of outputs. It means that banks with score lower than one have the potential to decrease their inputs to produce the same level of outputs and increase their efficiency level.

\subsection{Malmquist Productivity Change}

The Malmquist productivity index has five components which are used in performance measurement. They are efficiency change, pure efficiency change, scale efficiency change,technology change and change in total factor productivity. The Malmquist productivity index provides the opportunity of comparing the productivity change within the banking industry as well as to compare the productivity change within groups. Thus, poor performers could be catch up with the help of this measure. Total factor productivity as the term implies refers to all factors pertaining to the production of commercial banks, more specifically the change in total factor productivity entails the changes in efficiency and changes in technology. Malmquist total factor productivity is interpreted as follows:

The efficiency score greater than one indicates improvement or progression. On the other hand, the values less than one refers to the deterioration or regression. Whereas the values equal to one refers no improvement.The mean value of total factor productivity change (Malmquist Index) registered 1.008, indicating progress or annual average growth of $0.8 \%$ (Table 3 ). This positive productivity change can be dichotomized (decomposed) into its efficiency change and technology change components. Technology change represents the innovation in the banking system that has been developed, adapted, or absorbed by the banks. The mean value of technology changeregistered 1.005, indicating progress or positive technological change of annual $0.5 \%$. 
NRB Economic Review

Table 3: Malmquist Index Summary of Annual Means

\begin{tabular}{cccccc}
\hline $\begin{array}{c}\text { Fiscal } \\
\text { year }\end{array}$ & $\begin{array}{c}\text { Efficiency } \\
\text { change } \\
(\text { EFFCH) }\end{array}$ & $\begin{array}{c}\text { Technology } \\
\text { change } \\
\text { (TECHCH) }\end{array}$ & $\begin{array}{c}\text { Pure } \\
\text { efficiency } \\
\text { change } \\
\text { (PECH) }\end{array}$ & $\begin{array}{c}\text { Scale } \\
\text { efficiency } \\
\text { change } \\
\text { (SECH) }\end{array}$ & $\begin{array}{c}\text { Total factor } \\
\text { productivity } \\
\text { change } \\
\text { (TFPCH) }\end{array}$ \\
\hline $2011 / 12$ & 0.986 & 0.923 & 0.989 & 0.997 & 0.910 \\
$2012 / 13$ & 1.008 & 1.052 & 1.006 & 1.001 & 1.060 \\
$2013 / 14$ & 1.024 & 0.968 & 1.012 & 1.012 & 0.992 \\
$2014 / 15$ & 1.005 & 0.982 & 1.007 & 0.998 & 0.987 \\
$2015 / 16$ & 0.985 & 1.171 & 0.986 & 0.999 & 1.154 \\
$2016 / 17$ & 1.013 & 0.952 & 1.007 & 1.006 & 0.964 \\
\hline Mean & 1.003 & 1.005 & 1.001 & 1.002 & 1.008 \\
\hline
\end{tabular}

The efficiency change has the mean value of 1.003, which indicates an average growth of annual $0.3 \%$. The efficiency change is comprised of pure efficiency and scale efficiency changes. Pure efficiency change represents core efficiency due to improved operations and management while scale efficiency change is associated with returns to scale effects. Average pure efficiency change $(\mathrm{PECH})$ marked 1.001 , suggesting progress in terms of operations and management by $0.1 \%$ annually. And scale efficiency change $(\mathrm{SECH})$ resulted average value 1.002 , showing the positive scale economies effects and growth by $0.2 \%$.

The mean productivity change of individual banksduring seven yearsis shown in Table 4 . Out of the 28 commercial banks, 17 have total factor productivity score greater than one. This shows that approximately $61 \%$ of the banks are able to increase their total factor productivity during the study period of seven years. Out of the 28 only $10(35.7 \%)$ banks were able to increase their efficiency, whereas 11 (39\%) remained constant - neither progress nor regress in achieving efficiency. 
Table 4: Summary of Malmquist Productivity Index of Bank Means, 2010-2011 to 2016-2017

\begin{tabular}{lccccc}
\hline Banks & EFFCH & TECHCH & PECH & SECH & TFPCH \\
\hline ADB & 1.000 & 0.962 & 1.000 & 1.000 & 0.962 \\
BOK & 0.994 & 1.015 & 0.998 & 0.996 & 1.009 \\
CB & 0.995 & 0.966 & 1.000 & 0.995 & 0.961 \\
CCB & 1.000 & 0.937 & 1.000 & 1.000 & 0.937 \\
CZBI & 1.000 & 0.989 & 1.000 & 1.000 & 0.989 \\
EB & 0.996 & 1.032 & 0.996 & 1.000 & 1.028 \\
GBIME & 0.989 & 1.004 & 0.990 & 0.999 & 0.992 \\
HB & 1.013 & 1.008 & 1.000 & 1.013 & 1.021 \\
JBN & 1.000 & 1.004 & 1.000 & 1.000 & 1.004 \\
KB & 0.996 & 0.982 & 0.996 & 1.000 & 0.978 \\
LB & 1.008 & 0.994 & 1.007 & 1.000 & 1.002 \\
MB & 1.002 & 1.008 & 0.999 & 1.002 & 1.009 \\
MEGA & 1.016 & 0.978 & 1.014 & 1.003 & 0.994 \\
NABIL & 1.000 & 1.036 & 1.000 & 1.000 & 1.036 \\
NBB & 1.000 & 1.010 & 1.000 & 1.000 & 1.010 \\
NB & 1.019 & 1.043 & 1.000 & 1.019 & 1.063 \\
NCCB & 0.994 & 0.991 & 0.992 & 1.002 & 0.986 \\
NIB & 1.000 & 1.035 & 1.000 & 1.000 & 1.035 \\
NICA & 1.000 & 1.019 & 1.000 & 1.000 & 1.019 \\
NMB & 1.000 & 1.032 & 1.002 & 0.997 & 1.032 \\
NSBI & 1.017 & 1.019 & 1.017 & 1.000 & 1.036 \\
PCB & 1.000 & 1.020 & 1.000 & 1.000 & 1.020 \\
PRVU & 1.012 & 0.960 & 1.012 & 1.000 & 0.971 \\
RBB & 1.041 & 1.070 & 1.000 & 1.041 & 1.113 \\
SANIMA & 1.009 & 1.029 & 1.009 & 1.000 & 1.039 \\
SB & 1.006 & 0.978 & 1.007 & 0.999 & 0.984 \\
SCBN & 1.000 & 1.050 & 1.000 & 1.000 & 1.050 \\
SRB & 0.991 & 0.975 & 0.994 & 0.997 & 0.966 \\
\hline Mean & 1.003 & 1.005 & 1.001 & 1.002 & 1.008 \\
\hline & & & & \\
\hline
\end{tabular}

Note : $\mathrm{EFFCH}=$ Efficiency change; $\mathrm{TECHCH}=$ Technology change; $\mathrm{PECH}=$ Pure efficiency change; $\mathrm{SECH}=$ Scale efficiency change; TFPCH = Total factor productivity change; $\mathrm{ADB}=$ Agricultural Development Bank; BOK = Bank of Kathmandu; CB = Civil Bank; CCB = Century Commercial Bank; CZBI $=$ Citizen Bank International; EB = Everest Bank; GBIME = Global IME Bank; HB = Himalayan Bank; JBN = Janata Bank Nepal; KB = Kumari Bank; LB = Laxmi Bank; MB = Machhapuchchhre Bank; MEGA = Mega Bank; NABIL = Nabil Bank; NBB = Nepal Bangladesh Bank; NB = Nepal Bank; NCCB = Nepal Credit and Commerce Bank; NIB = Nepal Investment Bank; NICA = NIC Asia Bank; NMB = NMB Bank; NSBI = Nepal SBI Bank; PCB = Prime Commercial Bank; PRVU = Prabhu Bank; RBB = Rastriya Banijya Bank; SANIMA = Sanima Bank; SB = Siddhartha Bank; SCBN = Standard Chartered Bank Nepal; SRB = Sunrise Bank.

Efficiency change can be decomposed into pure efficiency change and scale efficiency change. As mentioned above, pure efficiency change represents core efficiency due to improved operations and management while scale efficiency change is associated with returns to scale effects. Only seven (25\%) of the Nepalese commercial banks have made 
progress in terms of pure efficiency while $14(50 \%)$ have remained constant during the study period. Only six $(21.5 \%)$ have improved and $16(57 \%)$ remained constant in terms of scale efficiency. Technology change represents the innovation in the banking system that has been used by the banks. A good number of Nepalese banks have made progress in obtaining technological efficiency as 17 (approx 61\%) have improved this efficiency. Mean values of the total factor productivity change, efficiency change, technology change, pure efficiency change and scale efficiency change scores are greater than one. This leads to infer that, on average, commercial banks have been improving their productivity and efficiency level. This finding is consistent with the findings of Neupane (2013) and Adjei-Frimpong, Gan, Ying, Hu, and Cohen (2015), who have also found a modest growth of banks productivity in their studies.

\subsection{Influence of Ownership Structure on Bank Efficiency}

Commercial banks in Nepal can be broadly categorized into three groups as public, private, and joint venture banks, on the basis of ownership and control. As of mid-July 2018, there werethree public banks, nineteen private sector banks, and six joint venture banks in operation. Rastriya Banijya Bank is the largest bank of Nepal in terms of deposit mobilization and is fully owned by the Government of Nepal. The Government of Nepal owns $51 \%$ ownership in the equity capital of Nepal Bank, another public bank. Likewise, Government of Nepal owns 51\% shares of Agricultural Development Bank that was initially established as a development bank with $100 \%$ government ownership and was upgraded to commercial bank in 2006. An attempt has been made here to analyze the influence of ownership structure on the efficiency of banks using the model specified in data and method section.

The estimated model is:

$$
\mathrm{Y}_{\mathrm{i}}=.974-.057 \mathrm{D}_{1}-.008 \mathrm{D}_{2}
$$

$$
\begin{array}{lccc}
\mathrm{t} \text {-value } & (116.511) & (-2.515) & (-.474) \\
\mathrm{p} \text {-value } & (.000) \quad(.019) & (.640) \\
& & \\
\mathrm{R}^{2} & .202 \quad \mathrm{DW}=1.897 \quad \mathrm{VIF}=1.034 \\
\mathrm{~F}=3.163(\mathrm{p} \text {-value }=.060)
\end{array}
$$

The mean efficiency score of the reference group (domestic bank) is .974 , obtained by substituting 0 for $\mathrm{D}_{1}$ and $\mathrm{D}_{2}$ in the estimated model. The mean efficiency score of the public bank is .917 (i.e. .974 minus .057) obtained by substituting 1 for $\mathrm{D}_{1}$ and 0 for $\mathrm{D}_{2}$ in 
the estimated model. The mean efficiency score difference between public bank and domestic bank is -.057, which is statistically significant at five percent level.

The mean efficiency score of the joint venture bank is .966 (i.e. .974 minus .008) obtained by substituting 0 for $\mathrm{D}_{1}$ and 1 for $\mathrm{D}_{2}$ in the estimated model. The mean efficiency score difference between joint venture bank and domestic bank is -.008, which is statistically not significant at five percent level. The mean efficiency level of domestic private banks, in terms of CRS efficiency score, is 0.974 whereas this level decreases by 0.057 (p-value $=.019)$ for public banks and by $.008(\mathrm{p}$-value $=.640)$ for joint venture banks. The difference in efficiency between domestic private banks and joint venture banks is statistically not significant, but between domestic private banks and public banks, the difference in efficiency is statistically significant. Domestic private banks ranked the highest in terms of efficiency, while joint venture banks and public banks ranked the second and the third respectively. These findings are consistent with the findings of Nigmonove (2010) and Thagunna and Poudel (2013) who also did not find any significant difference between the domestic banks and joint venture banks. However, the present study's findings are inconsistent with Sathye (2001) who found domestic banks are more efficient than foreign banks in Australia. Likewise,the results of present study differs with that of Yildri and Philippatos (2007) which infer that state owned banks are most efficient than other types of bank.

\subsection{Influence of Size on Banks Efficiency}

The regression of bank size on efficiency has been analyzed below following the model specification described in data and method section.

The estimated model is:

$$
\mathrm{Y}_{\mathrm{i}}=.978-.019 \mathrm{D}_{1}-.017 \mathrm{D}_{2}
$$

$$
\begin{array}{lccl}
\mathrm{t} \text {-value } & (73.814) & (-1.075) & (-.873) \\
\mathrm{p} \text {-value } & (.000) \quad(.293) & (.391) \\
& & & \\
\mathrm{R}^{2} & .049 \quad \mathrm{DW}=1.830 & \mathrm{VIF}=1.349 \\
\mathrm{~F}=.649 \quad(\mathrm{p} \text {-value }=.531) &
\end{array}
$$

The mean efficiency score of the reference group (small size bank) is .978 obtained by substituting 0 for $\mathrm{D}_{1}$ and $\mathrm{D}_{2}$ in the estimated model. The mean efficiency score of the medium size bank is .959 (i.e. .978 minus .019) obtained by substituting 1 for $D_{1}$ and 0 
for $\mathrm{D}_{2}$ in the estimated model. The mean efficiency score difference between medium size bank and small size bank is-.019, which is not significant at five percent level.

The mean efficiency score of the large size bank is .961 (i.e. .978 - .017) obtained by substituting 0 for $\mathrm{D}_{1}$ and 1 for $\mathrm{D}_{2}$ in the estimated model. The mean efficiency score difference between large size bank and small size bank is -.017, which is not significant at five percent level. The mean efficiency level of small size banks in terms of CRS efficiencyscore is 0.978 , whereas, this level decreases by 0.019 for medium size banks and by .017 for large size banks.As the mean efficiency scores among small, medium and large size banks are not significantly different at five percent level, the study rejects the hypothesis that "size of the banks makes significant difference in the increment of their efficiency and productivity level."This result is consistent with the result ofThagunna and Poudel(2013) but contrasts with the result ofSufian and Majid(2007) who found small size bank were poor in terms of efficiency.The resultdoes not confirm a priori expectation of the study that size takes a positive sign.

As mentioned in the data and methods section, bank efficiency score is again regressed on size of the bank without classifying the bank into different sizes, but taking the natural logarithm value of the total assets for size. This is to check the problem of bias that may arise due to the subjective classification of bank size in Model (ii.a). Regressing $\mathrm{Y}_{\mathrm{i}}$ (efficiency score) on $\operatorname{Ln}\left(\mathrm{SIZE}_{\mathrm{i}}\right)$, the estimated model is:

$$
\mathrm{Y}_{\mathrm{i}}=1.650-0.027 \operatorname{Ln}(\mathrm{SIZE})
$$

$$
\begin{array}{lll}
\mathrm{t} \text {-value } & (3.181) & (-1.319) \\
\mathrm{p} \text {-value } & (.004) & (.199)
\end{array}
$$

The independent variable, SIZE, as measured by the log of total assets is negative at $\beta_{1}=$ -.027 but statistically insignificant at the five percent level. Hence, it is deduced that the size of banks makes no significant difference in the efficiency level of banks. This result is similar to the result obtained by running the regression with classification of bank size and thus, supports the above classifications of banks assets into three classes.

\section{CONCLUSION}

This paper uses the DEA-based Malmquist Indexand measures the changes in total factor productivity and efficiency of Nepalese commercial banks during the period 2010-2011 to 2016-2017. The paper uses aggregate panel data covering all the 28 commercial banks that are currently operating in Nepal. The total factor 
productivity change, as measured by Malmquist productivity index, has been decomposed into efficiency change and technology change components. Technology change represents the innovation in the banking system. The efficiency change, again, has been decomposed into pure efficiency change and scale efficiency change. Pure efficiency change represents core efficiency due to improved operations and management while scale efficiency change is associated with returns to scale effects or economies of scale.

It is found that during the sample period Nepalese banks have nominally improved efficiencies inoperations and management, economies of scale, andinnovation in the banking system - measured in terms of pure efficiency change, scale efficiency change and technology change respectively. Total factor productivity, which entails the overall changes in efficiency and technology, showed a nominal progress during the studied period. Hence, it is concluded that Nepalese commercial banks have been improving their productivity and efficiency annually at marginal rate.The paper alsoconcludes that Nepalese private banksare relatively more efficient than joint venture and public banks.However, the size of banks makes no significant difference in the efficiency level of banks.

This paper has used input oriented approach of DEA, which basically attempts to investigate the efficiency of banks in mobilizing its inputs to produce outputs. Future research can be carried out using output oriented approach of DEA, which focuses on the efficiency of bank on producing the maximum outputs from the given level of inputs.

\section{REFERENCES}

Adjei-Frimpong, K., Gan, C., Ying, L., Hu, B., and D. Cohen. 2015. "Efficiency and productivity change in the banking industry: Empirical evidence from New Zealand banks." Investment Management and Financial Innovations, 12 (1), 1925 .

Aikaeli, J. 2008. "Commercial banks efficiency in Tanzania." Paper presented at the CSAE Conference on Economic Development in Africa, St. Catherine's College, Oxford, U K, 16-18 March 2008. 
Avkiran, N. K. 2004. "Decomposing technical efficiency and window analysis." Studies in Economics and Finance,22(1), 61-91.

Bahrini, R. 2017. "Efficiency analysis of Islamic banks in the Middle East and North Africa region: A bootstrap DEA approach." International Journal of Financial Studies, 5(7), 1-13. doi:10.3390/ijfs5010007

Berger, A. N. and D. B. Humphrey. 1997. "Efficiency of financial institutions: international survey and directions for future research." European Journal of Operational Research, 98, 175-212.

Caves, D. W., Christensen, L. R., and W. E. Diewert. 1982. "The economic theory of index numbers and the measurement of input, output, and productivity." Econometrica, 50(6), 1393-1414.

Coelli, T. J. 1996. "A guide to DEAP Version 2.1: A data envelopment analysis (computer) program." Working Paper 96/08, Centre for Efficiency and Productivity Analysis, University of New England, Armidale.

Coelli, T. J., Rao, D.S.P., O'Donnell, C. J., and G. E. Battese. 2005. An introduction to efficiency and productivity analysis (2nd ed.).New York: Springer.

Cooper, W. W., Seiford, L. M., and K. Tone. 2000. Data envelopment analysis: A comprehensive text with models, applications, references and DEA-Solver software. Boston: Kluwer Academic Publishers.

Eichengreen, B. and H. D. Gibson. 2001. "Greek banking at the dawn of the new millennium." CERP Discussion Paper 2791, London. Retrieved from https://www.researchgate.net/ profile/Heather_Gibson2/publication/4839180_ Greek_Banking_at_the_Dawn_of_the_New_Millennium/links/00b4951e7825c4 41dd000000/Greek-Banking-at-the-Dawn-of-the-New-Millennium.pdf

Evanoff, D. D. and P. R. Israilevich. 1991. "Productive efficiency in banking." Economic Perspectives, (na), 11-32.

Fare, R., Grosskopf, S., Lindgren, B., and P. Roos. 1992. "Productivity change in Swedish pharmacies 1980-1989: A nonparametric Malmquist approach." Journal of Productivity Analysis, 3, 85-102.

Fare, R., Grosskopf, S., Norris, M., and Z. Zhang. 1994. "Productivity growth, technical progress, and efficiency changes in industrialized countries." American Economic Review, 84, 66-83. 
Farne, M. and A. Vouldis. 2017. "Business models of the banks in the euro area." ECB Working Paper 2070.

Farrell, M. J. 1957. "The measurement of productivity efficiency." Journal of the Royal Statistical Society, 120(3), 253-281.

Fisher, R. A. 1922. "On the mathematical foundations of theoretical statistics. " Philosophical Transactions of the Royal Society of London, 222, 309-368.

Garamu, G. 2016. "Technical efficiency and productivity of Ethiopian commercial banks: Data envelopment analysis (DEA) approach." International Journal of Scientific and Research Publications, 6(9), 860-864.

Hamid, M. A. and S. M. Azmi. 2011. "The performance of banking during 20002009: Bank Islam Malaysia Berhad and conventional banking in Malaysia." International Journal of Economics and Management Sciences, 1(1), 09-19.

Hassan, M. K. 2005. "The cost, profit and X-efficiency of Islamic banks." Paper presented at the 12th ERF Annual Conference, 19th-21st December, Egypt.

Jatic, S. and M. Ilic. 2018. "Traditional and new business models in the banking industry." Bankarstvo, 47(1), 106-117. doi: 10.5937/bankarstvo1801106J

Malmquist, S. 1953. "Index numbers and indifference curves." Trabajos de Estatistica, 4(1), 209-242.

Meenakumari, R. 2009. Investigation on the operational performance of state owned electric utilities in India. (Doctoral thesis, Faculty of Electrical Engineering, Anna University Chennai). Retrieved from https://shodhganga.inflibnet.ac.in/ handle/10603/28108

Nepal Rastra Bank. 2017. Bank supervision report. Kathmandu: Nepal Rastra Bank, Bank Supervision Department. Retrieved from https://nrb.org.np/bsd/ reports/Annual_Reports--Annual_Bank_Supervision_Report_2016.pdf

Nepal Rastra Bank. 2018. Monetary Policy for 2018/19. Kathmandu: Nepal Rastra Bank. Retrieved from https://www.nrb.org.np/ofg/monetary_policy/ Monetary _Policy_(in_English)--2018-19_(Full_Text).pdf

Neupane, B. 2013. "Efficiency and productivity of commercial banks in Nepal: A Malmquist index approach." Asian Journal of Finance and Accounting, 5(2), 220-243. 
Nigmonov, A. 2010. "Bank performance and efficiency in Uzbekistan."Eurasian Journal of Business and Economics, 3, 1-35.

Olweny, T. and T. M. Shipho. 2011. "Effects of banking sectoral factors on the profitability of commercial banks in Kenya." Economics and Finance Review, 1(5), 1-30.

Pathak, H. P. 2017. Impact of mergers and acquisitions on operating performance of Nepalese financial institutions (Unpublished $\mathrm{PhD}$ dissertation). The Office of the Dean, Faculty of Management, Tribhuvan University, Kathmandu, Nepal.

Ramanathan, R. 2003. An introduction to data envelopment analysis: A tool for performance measurement. New Delhi: Sage Publication.

Reisman, A., Daouas, M., Oral, M., Rebai, S., and S. Gattoufi. 2003. "Impact of deregulation on technical and scale efficiencies of Tunisian commercial banks: Window extended data envelopment analysis." Working Paper, Faculte des Sciences Economiques et de Gestion de Tunis, Universite El Manar, Tunisie.

Roengpitya, R., Tarashev, N., Tsatsaronis, K., and A. Villegas. 2017. "Bank business models: Popularity and performance." BIS Working Papers No. 682. Retrieved from https://www.bis.org/publ/work682.pdf

Rose, P. S. and S. C. Hudgins. 2008. Bank management and financial services (8th ed.). New Delhi: McGraw-Hill Education.

Sathye, M. 2001. "X-Efficiency in Australian banking: An empirical investigation." Journal of Banking and Finance, 25, 613-630.

Sathye, M. 2002. "Measuring productivity changes in Australian banking: An application of Malmquist Indices." Managerial Finance, 28(9), 48-59. doi: $10.1108 / 03074350210768068$

Sengupta, J. K. 1995. Dynamics of data envelopment analysis: Theory of systems efficiency. Dordrecht: Kluwer.

Sinha, R. P. and B. Chatterjee. 2008. "Fund-based activity of commercial banks: A Malmquist approach." Indian Economic Review, 43(1), 83-102.

Sufian, F. and M. A. Majid. 2007. "Bank ownership, characteristics and performance: A comparative analysis of domestic and foreign Islamic banks in Malaysia." Munich Personal RePEc Archive, MPRA Paper No. 12131. Retrieved from https://mpra.ub.uni-muenchen.de/12131/1/MPRA_paper_12131.pdf 
Sufian, F. and M. S. Habibullah. 2010. "Bank-specific, industry-specific and macroeconomic determinants of bank efficiency: Empirical evidence from the Thai banking sector." The Journal of Applied Economic Research, 4(4), 427-461.

Thagunna, K. S. and S. Poudel. 2013. "Measuring bank performance of Nepali banks: A data envelopment analysis (DEA) perspective." International Journal of Economics and Financial Issues, 3(1), 54-65.

Tornqvist, L. 1936. "The Bank of Finland's consumption price index." Bank of Finland Monthly Bulletin, 10, 1-8.

Webb, R. 2003. "Levels of efficiency in UK retail banks: A DEA window analysis." International Journal of the Economics of Business, 10(3), 305-322.

Yildrim, S., and G. Philippatos. 2007. "Efficiency of banks: Recent evidence from the transition of economies of Europe, 1993-2000." The European Journal of Finance, 13(2), 123-143. doi:10.1080/13518470600763687 